\title{
From the numerical model to the educational software : Lake Life
}

\author{
J.M. Thébault' \\ M.J. Salençon ${ }^{2}$
}

Keywords : Ecosystem model, educational software, hydroelectric reservoir.

"Lake Life » is a software program designed to introduce the lay person to lacustrian ecology and to the basic concepts of hydraulic management. Having become familiar with the dynamics of the trophic system as well as the mechanisms leading to eutrophication, the user may experiment with managing the reservoir of his choice. Change over time in the principal elements in the ecosystem is calculated by a mathematical model. This paper first presents the successive steps in development of the model :

- choice of variables : three plankton groups, fish, nutrients, oxygen ;

- representation of complex mechanisms : for example, the vertical structure simulated in two layers ;

- transcription into equations.

This recapitulation will initiate the reader into the problems of modeling an ecosystem.

We shall then analyse a few simulated situations : variations in plankton groups in three situations with increasing trophism, and one example of the impact of turbining on the fish and planktonic populations and on oxygenation of the hypolimnion. The quite realistic behavior of the simulations makes this software an excellent teaching tool.

\section{Du modèle numérique au logiciel didactique : la vie du lac}

Mots clés : Modèle d'écosystème, logiciel didactique, retenue hydroélectrique.

« La Vie du lac » est un logiciel destiné à initier un public non averti à l'écologie lacustre et aux notions fondamentales de la gestion hydraulique. Après avoir pris connaissance du fonctionnement de la chaîne trophique ainsi que des mécanismes conduisant à l'eutrophisation, l'utilisateur a la possibilité de gérer une retenue de son choix. L'évolution dans le temps des principales composantes de l'écosystème est calculée par un modèle mathématique. Nous présentons icí les étapes successives qui ont permis l'élaboration du modèle :

- le choix des variables : trois groupes planctoniques, poissons, nutriments, oxygène ;

- la schématisation de mécanismes complexes : par exemple la structure verticale simulée en deux couches ;

- la mise en équations.

Cette démarche constitue une bonne initiation à la modélisation d'un écosystème.

Nous analysons ensuite quelques simulations : l'évolution des communautés planctoniques dans trois situations de trophie croissante, puis un exemple de l'impact du turbinage sur les populations et sur l'oxygénation de l'hypolimnion. Le comportement suffisamment réaliste des simulations permet d'utiliser ce logiciel comme support de cours pour l'enseignement.

\section{Introduction}

" Lake Life » is a software program designed to describe for a lay public the manner in which a lacustrian ecosystem reacts to disturbances, whether natural or related to human activities. Making use of

1. Laboratoire d'Hydrobiologie, URA 695 du CNRS, Université Paul Sabatier, 118. Route de Narbonne, 31062 Toulouse Cedex, France.

2. Electricité de France, Direction des Etudes et Recherches, Département Environnement, 6, Quai Watier, 78401 Chatou Cedex, France. animated images, a choice of information level, and a user-friendly mouse, it gives an attractive presentation of the various components in a lacustrian ecosystem : nutrients, phyto- and zooplankton, fish, etc. It also describes the principal mechanisms at work : thermal stratification, interaction of various kinds among the links in the trophic chain and the dynamics of eutrophication.

Once these fundamental concepts have been reviewed, the user is asked to choose a lake type characterized by the period required for renewal of water, 
and to assume control over its future by managing nutrient concentrations, parameters of hydraulic management (withdrawal levels and period) as well as any stocking with young fish. Critical periods (during which water is unfit for swimming, fish survival, etc.) are indicated by alarms. The user's goal is, of course, to fight eutrophication while integrating those mechanisms which contribute to maintaining water quality.

In order for a simulation closely to approach reality, it is necessary to use a numerical model which simulates the ecosystem dynamics. The great number of possible responses the model may give, depending on the user's choice and the history of the reservoir, precludes use of pre-established scenarii. The model performs « on-line » calculation of variations in the main ecosystem components, before the user's eyes, enabling him to visualize continually the repercussions of his system management. This approach closely parallels that made of decision-support models, and is, for that reason, a good introduction to one of the key functions of modeling.

The "Lake Life " model is a simplified version of the computer code perfected for study of Pareloup Lake (Thébault \& Salençon 1992).

This paper presents the concepts behind the model, the choice of trophic network and variables, as well as the simplifying hypotheses it was necessary to make. One of the major problems confronting us was to find a compromise between the model's complex form of representation, integrating to a high degree present hydrobiological know-how in the field of reservoir ecology, and a calculating time which seemed reasonable for a microcomputer.

The purpose of the model is above all pedagogical ; for this reason, it is essential that the simulations be characteristic - even caricatures, in a sense - so as to constitute « teaching cases " which can easily be assimilated by the user. Only the predominant system mechanisms have therefore been selected. With apologies to the specialists, we have simplified to the extreme the more complex mechanisms.

For all these reasons, this model can absolutely not be used as a management tool, and even less as a research tool.

The software runs on Atari or PC-compatible computers ; simulation of one year requires approximately two minutes' calculating time. This is between 1000 and 5000 times faster than the time it would take similar computers to run an actual management model of the Pareloup type.

\section{Description of the model}

\subsection{Physical structure}

The physical structure of the system is one of the elements in the program which required the greatest simplification, essentially for reasons of computer memory. The water mass is divided vertically into two homogeneous layers which represent seasonal thermal stratification. The surface layer, the epilimnion, is separated from the bottom layer, the hypolimnion, by a thermocline. The bottom layer is in contact with sediment.

Each layer is characterized by its temperature, volume, depth and mean illumination. The dynamics of the two water masses are simulated in two phases : one phase of homogeneity in winter, when only the epilimnion exists, and one phase of stratification in summer, when the thermocline level is constant. It was impossible to introduce the transient spring thermoclines, variations in depth of the thermocline or the gradual deepening of the thermocline in autumn. Thus, the onset of stratification and the autumn mixing are instantaneous !

Inflow and outflow of water are represented very schematically : inflow is always localized in the surface layer ; outflow due to turbining may be at the surface or on the bottom, with the user free to determine the outlet level for each season.

The program proposes a choice among three types of reservoir, characterized by the period required for water renewal : a short.residence time of from two weeks to a month (Grangent, for example), from one to three months (as for Chambon, for example), and on the order of one year for reservoirs with a protracted residence time (such as Pareloup and Sainte-Croix). The length of the period of stratification and exchange between the two layers differ according to the type of reservoir : in the first case, no stratification is introduced ; in the second, there is stratification, but there is nonetheless a low but constant amount of exchange between the two layers ; in the third case, stratification lasts from late spring to mid-autumn, and there is no exchange except in the event of turbining. For the last two 
reservoir types, turbining through the lower outlet triggers movement from the epilimnion toward the hypolimnion.

There are two possible sources of phosphorus and nitrogen : concentrations from upstream and any discharge of water containing some concentrations of these same elements. The residence time determines the annual inflow-outflow rate. All variables, with the exception of fish, are withdrawn by turbining.

\subsection{The variables}

Forcing variables :

These variables are directly entered into the model and are therefore not calculated :

- respective volumes of the two layers and of the sediment,

- inflow and outflow rates,

- concentration of $\mathbf{N}$ and $\mathbf{P}$ in inflow,

- mean light energy in the epilimnion, represented schematically by a sine curve with a period of 365 days. It is supposed that light energy in the hypolimnion is too low to permit algal growth;

- the temperature of each layer, also represented by a sine curve. During stratification, the hypolimnion temperature remains low and stable.

State variables in the model :

The model is based on a phosphorus budget, which is to say that all variables, with the exception of nitrogen and dissolved oxygen, are expressed in phosphorus units.

Phytoplankton are divided into two groups : algae which may be consumed by the zooplankton, and Cyanobacteria, capable of fixing atmospheric nitrogen and not consumed by the zooplankton.

In order to limit the number of variables, we do not simulate silica and therefore do not distinguish a diatom group.

Nutrients : both groups of algae need phosphorus. We have introduced nitrogen as it may be a limiting factor. It is consumed by both groups of algae, but is not indispensable tn Cyanobacteria.

Zooplankton : our experience at Pareloup led us to distinguish a single group of herbivorous zooplankton, as the impact of carnivorous zooplankton is limited in comparison with predation by plankton-grazing fish.
The fish prey on zooplankton. We assume here that the population is homogeneous over time, which permits introduction of a single variable.

Detritus is composed of algae and dead animals, phytoplankton which has settled, and matter not assimilated by animals. Bacteria are not simulated in this model. We assume that they are constantly effective in mineralizing organic matter.

Oxygen is an important indicator of water quality, and determines the possibility for survival of most fish species. This variable is therefore included in the model.

\subsection{Modeled processes}

The diagram of the model dynamics is summarized in Figure 1 ; all equations and variables in Tables $1,2,3,4$ and 5 .

\section{Phytoplankton}

The factors for phytoplankton production include light, temperature and nutrient concentration : all factors which can curb the phytoplankton growth rate, especially in ranges of values far off optimum values.

We have used Monod's equation (1942), a hyperbolic function which is well suited to description of the relationship between phytoplankton growth and nutrient concentration. We have chosen a similar equation to represent the effect of light and temperature, introducing a threshold value below which there is no growth. These functions are less sophisticated than those used in more complete models (Steele 1962, Parker 1974, Eilers \& Peters 1988, Talbot et al. 1991) : in particular, they do not simulate the drop in growth rate at high temperatures or under conditions of photo-inhibition, which is less important in this model. They are, on the other hand, far simpler to calculate.

Real growth is defined as the product of a maximum growth rate and the three limiting factors.

The two groups of algae need phosphorus and nitrogen for development. The first group is limited by the least abundant element (Leibig law : Droop 1974, 1975, Rhee 1978).

Cyanobacteria are limited only by a phosphorus deficit ; they are capable of fixing atmospheric nitrogen when mineral nitrogen is lacking. 
Factors in disappearance : predation by zooplankton and sinking are the factors for disappearance of the first group of algae. At least two causes may be found for major variations in sinking speed. One is physical, related to turbulence in the medium, and cannot be simulated here ; the other depends on numerous factors such as cell size, temperature, age of the population or lack of nutriment. We chose this latter factor for our model, linking sinking speed to growth limitation due to nutrients.

Natural mortality is considered to be a negligible factor in comparison to predation and sinking.

Cyanobacteria can generally not develop in a turbulent medium and at low temperatures (Steinberg \& Hartman 1988, Zohary \& Breen 1989). As we do not simulate turbulence, we have linked mortality in this group of algae to temperature; field observations at Pareloup indicate that, generally speaking, agitation in the water mass is at its maximum level in winter and spring, when the temperature is the lowest.

\section{Zooplankton}

The rate of ingestion depends primarily in the short term on temperature and nutrient concentration. We have simplified the model proposed by Thébault (1985) which permits simulation of their compounded effect. The function linking ingestion to the quantity of available prey has been replaced by a hyperbolic function (Mullin et al. 1975). To this, we have added a threshold below which feeding is nil. Only the " maximum feeding » coefficient is a function of the temperature. This simplification permits a considerable reduction in the number of coefficients needed.

Rates of assimilation and natural mortality are constant. Predation by fish, the principal cause of

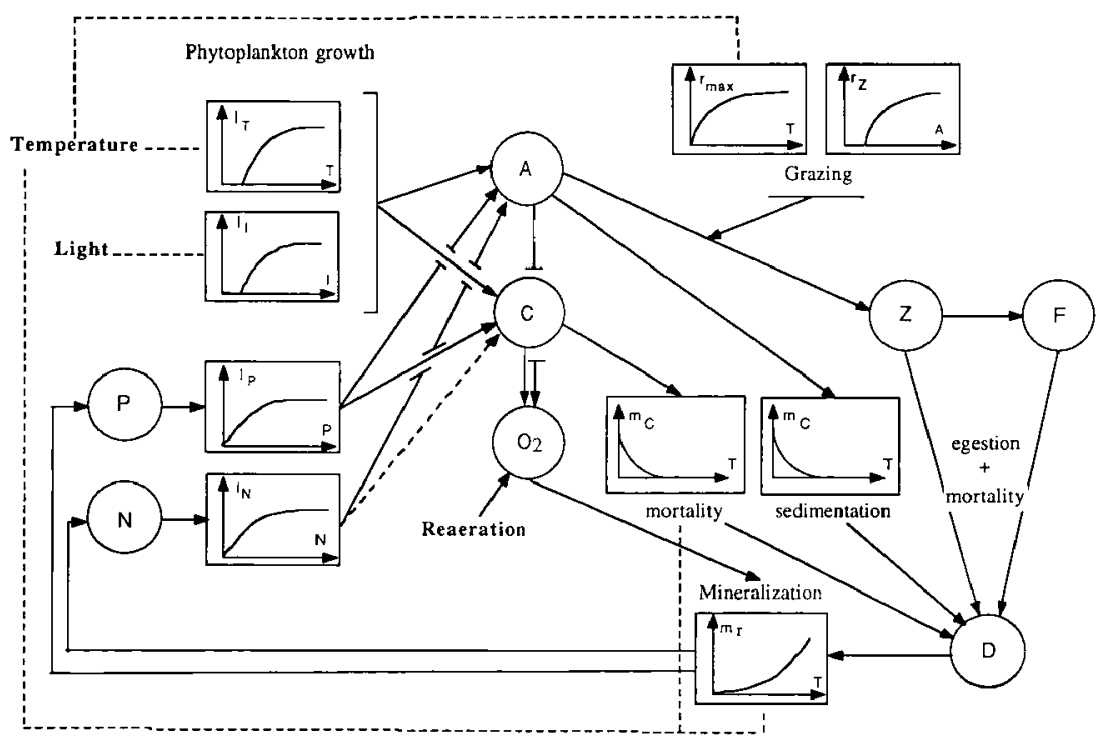

Fig. 1. Diagram of the dynamics of the biological model.

Fig. 1. Diagramme de fonctionnement du modèle biologique. 
zooplankton disappearance, is directly proportional to the fish population.

Fish

We assume that the population is stable over time, neither increasing nor decreasing under normal conditions of oxygenation. Below a first threshold for concentration of dissolved oxygen, the most fragile fish (the Salmonidae) die. If concentrations of dissolved oxygen continue to drop, no fish survive.

Detritus and nutrients

Detritus settles at a constant rate. Phosphorus and nitrogen are mineralized from detritus, in what is no more than transformation from an organic to a mineral form, the speed of which is temperaturedependent. We do not distinguish the different forms of nitrogen or phosphorus. A fraction of these elements is stored in sediment and later released into the hypolimnion when it is anoxic (insufficient oxygen).

Dissolved oxygen

Dissolved oxygen is produced as a result of photosynthesis attributable to phytoplankton and gaseous exchange at the air-water interface, or reaeration. Such exchange is faster from autumn to spring, the period during which wind speed is generally higher.

\subsection{Numerical considerations}

As certain growth rates are extremely high (a high value for the derivative), one needs to have a small integration time step. We usually use the Runge and Kutta fourth-order method for numerical integration (Legras 1971) in solving differential equations in biological models. While this method is highly simple, it calculates the totality of the equations and related subroutines four times per time step. The finite difference method is quicker (as calculation is performed once only), but less precise for an identical time step. Error due to numerical integration (and to a lesser degree to computer error) can be estimated by calculating a mass budget. A compromise between acceptable error for this type of software and speed in calculation led us to solve equations by means of finite differences with a time step of $1 / 10$ of a day.
Table 1. Sedimentation process.

Tableau 1. La sédimentation.

$$
\begin{aligned}
& a \frac{\partial X_{i}}{\partial t}=S_{X_{i}} \frac{\partial a X_{i}}{\partial z} \\
& \frac{\partial X_{i}}{\partial t}=S_{X_{i}} \frac{\partial X_{i}}{\partial z}
\end{aligned}
$$

Sedimentation in top layer

$$
\mathrm{V}_{1} \frac{\Delta \mathrm{X}_{1}}{\Delta \mathrm{t}}=-\underbrace{\mathrm{S}_{\mathrm{X}_{1}} \mathrm{aX}}
$$

to botton layer

Sedimentation in bottom layer

$$
\mathrm{V}_{2} \frac{\Delta \mathrm{X}_{2}}{\Delta \mathrm{t}}=\underbrace{\mathrm{S}_{\mathrm{X}_{1}} \mathrm{aX_{1 }}}_{\begin{array}{c}
\text { from top } \\
\text { layer }
\end{array}}-\underbrace{\mathrm{S}_{\text {to sediment }}}_{\mathrm{X}_{2} a \mathrm{X}_{2}}
$$

\section{Sedimentation into sediment layer}

$$
\begin{aligned}
& \mathrm{V}_{\mathrm{S}} \frac{\Delta \mathrm{X}_{\mathrm{S}}}{\Delta \mathrm{t}}=\mathrm{S}_{\mathrm{X}_{2}} \mathrm{aX}_{2} \\
& \text { for } \mathrm{X}=\mathrm{A}, \mathrm{C}, \mathrm{D} \\
& \mathrm{a}=\text { mean area of the lake. }
\end{aligned}
$$

In order to simplify expressions, sedimentation corresponding to each layer $i$ and variable $X$ has been written in table 2 :

$$
\mathrm{S}_{\mathrm{X}_{\mathbf{i}}} \frac{\partial \mathrm{X}_{\mathrm{i}}}{\partial \mathrm{z}}
$$


Table 2. System of differential equations.

Tableau 2. Le systèrne des équations diffèrentielles.

In water layers

$$
\begin{aligned}
& \frac{\partial \mathrm{A}_{1}}{\partial \mathrm{t}}=\left(\mathrm{g}_{\mathrm{A}}-\frac{\mathrm{S}_{1}}{\mathrm{~V}_{1}}\right) \mathrm{A}_{1}-\mathrm{r}_{\mathrm{Z}} \mathrm{Z}-\mathrm{s}_{\mathrm{A}} \frac{\partial \mathrm{A}_{1}}{\partial \mathrm{Z}} \\
& \frac{\mathrm{dC}_{1}}{\mathrm{dt}}=\left(\mathrm{gC}_{\mathrm{C}}-\mathrm{m}_{\mathrm{C}}-\frac{\mathrm{S}_{1}}{\mathrm{~V}_{\mathrm{l}}}\right) \mathrm{C}_{1} \\
& \frac{d Z}{d t}=\left(\alpha_{Z} r_{Z}-\mu_{Z}-\frac{S_{i}}{V_{i}}\right) Z-p_{F} F \\
& \frac{\mathrm{dF}}{\mathrm{dt}}=\left(\alpha_{\mathrm{F}} \mathrm{p}_{\mathrm{F}}-\mu_{\mathrm{F}}\right) \mathrm{F} \\
& \frac{\partial D_{1}}{\partial t}=m_{C} C_{1}+\left(\left(1-\alpha_{Z}\right) r_{Z}+\mu_{Z}\right) Z+\left(\left(1-\alpha_{F}\right) p_{F}+\mu_{F}\right) F-\left(m_{r}+\frac{S_{1}}{V_{1}}\right) D_{1}-v_{D} \frac{\partial D_{1}}{\partial z} \\
& \frac{\partial D_{2}}{\partial t}=s_{A} \frac{\partial A_{1}}{\partial z}+v_{D} \frac{\partial D_{1}}{\partial z}+\left(\left(1-\alpha_{Z}\right) r_{Z}+\mu_{Z}\right) Z+\left(\left(1-\alpha_{F}\right) P F+\mu_{F}\right) F-\left(m_{r}+\frac{s_{2}}{v_{2}}\right) D_{2}-v_{D} \frac{\partial D_{2}}{\partial z} \\
& \frac{\mathrm{dP}}{\mathrm{dt}}=\mathrm{XP}_{\mathrm{P}} \frac{\mathrm{E}}{\mathrm{V}_{1}}+\mathrm{m}_{\mathrm{r}} \mathrm{D}_{\mathrm{l}}-\mathrm{g}_{\mathrm{A}} \mathrm{A}_{\mathrm{l}}-\mathrm{gCC}_{1}-\frac{\mathrm{S}_{1}}{\mathrm{~V}_{\mathrm{l}}} \mathrm{P}_{\mathbf{l}} \\
& \frac{d P_{2}}{d t}=m_{r} D_{2}-\left(\psi_{P}+\frac{S_{2}}{V_{2}}\right) P_{2}+\varphi_{P} P_{S} \frac{V_{S}}{V_{2}} \\
& \frac{d N_{1}}{d t}=X_{N} \frac{E}{V_{1}}+m_{r} D_{1} n p-g_{A} A_{1} n p-g C C_{1} n p-\frac{S_{1}}{V_{1}} \\
& \frac{d N_{2}}{d t}=m_{r} D_{2} n p-\left(\psi_{N}+\frac{S_{2}}{V_{2}}\right) N_{2}+\varphi_{N} N_{S} \frac{V_{S}}{V_{2}} \\
& \frac{\mathrm{dO}_{1}}{\mathrm{dt}}=\max \left(\mathrm{O}_{\mathrm{sat}}, \lambda+\phi_{\mathrm{P}}\left(\mathrm{g}_{\mathrm{A}}+\mathrm{g}_{\mathrm{C}}\right)-\phi_{\partial \mathrm{x}} \mathrm{m}_{\mathrm{r}} \mathrm{D}_{1} \cdot \frac{\mathrm{S}_{1}}{\mathrm{~V}_{1}} \mathrm{O}_{1}\right. \\
& \frac{\mathrm{dO}_{2}}{\mathrm{dt}}=-\phi_{\mathrm{ox}} \mathrm{m}_{\mathrm{r}}\left(\mathrm{D}_{2}+\mathrm{D}_{\mathrm{S}}\right)-\frac{\mathrm{S}_{2}}{\mathrm{~V}_{2}} \mathrm{O}_{2}
\end{aligned}
$$

In sediment

$\frac{d D_{S}}{d t}=v_{D} \frac{\partial D_{2}}{\partial z}-m_{s} D_{S}$

$\frac{d P_{S}}{d t}=\psi_{\mathrm{p}} P_{2}+m_{\mathrm{r}} D_{S}-\varphi_{\mathrm{P}} P_{S}$

$\frac{d N_{S}}{d t}=\psi_{N} N_{2}+m_{r} D_{S n p}-\varphi_{N} N_{S}$ 
Table 3. Model variables.

Tableau 3. Les variables du modele.

$\begin{array}{ll}\text { Forcing variables } \\ \text { I } & \text { Mean solar irradiance in the upper layer } \\ T_{1}\left(T_{2}\right) & \text { Temperature of the upper (lower) layer } \\ V_{1}\left(V_{2}\right) & \text { Volume of the upper (lower) layer } \\ V_{S} & \text { Volume of the sediment layer } \\ X_{N}, X_{P} & \text { Concentration of variables } N \text { and } P \text { in the inflow } \\ E & \text { Inflow in top layer } \\ S_{i} & \text { Outflow from layer } i, i=1,2\end{array}$

\section{State variables}

A Phytoplankton grazed by herbivorous zooplankton, $i=1$

$\mathrm{C}_{\mathbf{i}} \quad$ Cyanobacteria, $\mathrm{i}=1$

z Herbivorous zooplankton

F Fish

Di Detritus, $i=1.2 .5$

$P_{1} \quad$ Dissolved inorganic phosphorus, $i=1,2,5$

$\mathrm{N}_{\mathrm{i}} \quad$ Dissolved inorganic nitrogen, $\mathrm{i}=1,2, \mathrm{~S}$

$\mathrm{O}_{\mathrm{i}} \quad$ Dissolved oxygen, $\mathrm{i}=1,2$

$\mathbf{i}=1:$ top layer

$\mathrm{i}=2$ : bottom layer

$\mathfrak{i}=\mathrm{S}$ : sediment layer
Table 4. Processes represented in the model. Tableau 4. Les processus représentés dans le modèle.

\section{Phytoplankton growth}

Effect of light

$$
\begin{array}{ll}
\text { if } I>\sigma_{1} & 1_{I}(I)=\frac{I-\Phi_{l}}{x_{1}+I-2 \sigma_{I}} \\
\text { if } I \leq \pi_{1} \quad l_{I}(I)=0
\end{array}
$$

Effect of temperature

$$
\begin{aligned}
& \text { if } T>\sigma_{T} \quad l_{T}(T)=\frac{1-\omega_{T}}{\kappa_{T}+T-2 \sigma_{T}} \\
& \text { if } T \leq \sigma_{T} \quad l_{T}(T)=0
\end{aligned}
$$

Effect of nutrients

$$
\begin{aligned}
& I_{P}=\frac{P}{\kappa_{P}+P} ; I_{N}=\frac{N}{K_{N}+N} \\
& I_{M}=I_{P} \text { for Cyanobacteria } \\
& I_{M}=\operatorname{Min}\left(I_{P}, 1_{N}\right) \text { for other algae }
\end{aligned}
$$

Growth rate: $\mathrm{g}=\mathrm{g} \mathrm{l}_{\mathrm{I}} \mathrm{l}_{\mathrm{T}} \mathrm{l}_{\mathrm{M}}$

Cyanobacteria mortality

$$
\begin{aligned}
& \text { if } T \leq \varpi_{m} \quad m_{C}(T)=\mu_{t \operatorname{sax}}\left(\begin{array}{cc}
1-\frac{T}{\sigma_{m}}
\end{array}\right) \\
& \text { if } T>\sigma_{i n} \quad m_{C}(T)=0
\end{aligned}
$$

Sedimentation

$$
\begin{aligned}
& \text { if } l_{M} \leq \omega_{S} \quad s_{A}\left(l_{M}\right)=v_{\max }\left(1-\frac{l_{M}}{\omega_{S}}\right) \\
& \text { if } l_{M}>a_{S} \quad s_{A}\left(l_{M}\right)=0
\end{aligned}
$$

Zooplankton

Effect of temperature on maximum ingestion rate

$$
\begin{gathered}
\text { Ingestion rate } \\
\quad \mathrm{r}_{\max }(\mathrm{T})=\tau_{\mathrm{Z}} \frac{\mathrm{T}}{\mathrm{K}_{\mathrm{TZ}}+\mathrm{T}} \\
\text { if } \mathrm{A}>\boldsymbol{\omega}_{\mathrm{A}} \quad \mathrm{r}_{\mathrm{Z}}(\mathrm{A})=\mathrm{r}_{\max } \frac{\mathrm{A} \cdot \boldsymbol{\omega}_{\mathrm{A}}}{\mathrm{K}_{\mathrm{A}}+\mathrm{A} \cdot 2 \sigma_{\mathrm{A}}} \\
\text { if } \mathrm{A} \leq \omega_{\mathrm{A}} \quad \mathrm{r}_{2}(\mathrm{~A})=0
\end{gathered}
$$

Fish

Ingestion rate

$$
\begin{aligned}
& \text { if } Z>\omega_{Z} \quad \operatorname{pr}(Z)=\tau_{F} \frac{Z-\omega_{Z}}{\kappa_{Z}+Z-2 \omega_{Z}} \\
& \text { if } Z \leq \omega_{Z} \quad p_{F}(Z)=0
\end{aligned}
$$

Nutrient regeneration from detritus:

$$
m_{r}(T)=\alpha_{r} e^{\beta_{1} T}
$$




\section{Simulation results}

Table 5. Model parameters.

Tableau 5. Les paramètres du modèle.

\begin{tabular}{|c|c|}
\hline \multicolumn{2}{|c|}{ Phyloplankton paramesers } \\
\hline$\kappa_{1}, \kappa_{T}, \kappa_{\mathrm{P}}, \kappa_{\mathrm{N}}$ & $\begin{array}{l}\text { Half-saturation coefficient for limitation by respectively } \\
\text { light, temperature, phosphorus and nitrogen }\end{array}$ \\
\hline $\mathbf{w}_{\mathbf{i}}, \mathbf{m}$ & Light and temperanre thresthold for growth \\
\hline $\boldsymbol{\gamma}$ & Maximum growth rate for algae \\
\hline $\mathbf{m}$ & Temperature threshold for Cyanobacteria mortality \\
\hline$\mu_{\max }$ & maximum mortality rate for Cyanobacteria \\
\hline np & $N: P$ ratio for all variables \\
\hline \multicolumn{2}{|c|}{ Sedimentation paramesers } \\
\hline$v_{\operatorname{mox}}$ & Maximum sedimentation raue \\
\hline $\boldsymbol{\Phi}_{\mathbf{s}}$ & Nutrient threstold betow which sedimentation begins \\
\hline$v_{\mathbf{b}}$ & Constant sedimentation rate for detritus \\
\hline$\psi_{p}=\psi_{N}$ & Uptake of $P$ and $N$ by sediment \\
\hline$\Phi_{\mathbf{P}} \boldsymbol{\Phi}_{\mathbf{N}}$ & Release of $\mathrm{P}$ and $\mathrm{N}$ from sediment \\
\hline \multicolumn{2}{|c|}{ Animal parameters } \\
\hline$\tau_{\mathrm{z}} \tau_{\mathrm{F}}$ & $\begin{array}{l}\text { Maximum ingestion rate at optimal lemperature for } \\
\text { respectively zooplankton and fish }\end{array}$ \\
\hline$\kappa_{\text {Tz }}$ & Half-saturation coefficient for $r_{\operatorname{man}}(\mathrm{T})$ \\
\hline $\boldsymbol{\omega}_{\boldsymbol{A}}$ & Threshold concentration of algae for zooplankton feeding \\
\hline $\mathbf{w}_{\mathbf{2}}$ & Threshold concentration of zooplarkion for fish feeding \\
\hline$x_{A_{1}}, x_{2}$ & Half-saturation coefficient for $r_{z}(A)$ and $p_{F}(Z)$ \\
\hline$\alpha_{2}, \alpha_{F}$ & Assimilation rate \\
\hline$\mu_{2} \mu_{F}$ & Mortility rate \\
\hline \multicolumn{2}{|c|}{ Nutrient regeneraxion and oxygen parameters } \\
\hline$\alpha_{r}, \beta_{r}$ & Coefficients for $\mathbf{m}_{\mathbf{r}}(\mathrm{T})$ \\
\hline$\lambda$ & Diffusion of oxygen at the lake surface \\
\hline$\phi_{\mathbf{p}}$ & Oxygen produced by photosynthesis \\
\hline 4a & Oxygen used in organic decay of delritus \\
\hline $\mathbf{O}_{-\infty}$ & Saturated oxygen conocriration \\
\hline
\end{tabular}

The most interesting simulations from an educational point of view are those related to reservoirs where the residence time is seasonal or annual. The management scenarii the user adopts here can significantly modify the future of the reservoir, unlike the case of the reservoir with a low residence time where it is impossible to exercise any influence on eutrophy in the river.

In our model, when there is no hydroelectric power generation, the flow left above the dam is equal to inflow from the watershed. We can suppose that, in this case, the lake behaves like a natural lake.

When the nutrient concentrations are low (Simulation 1, Fig. 2), we note a springtime increase in phytoplankton, followed by an increase in herbivorous zooplankton. In the summer, when the lake is stratified, nutrients become a growth-limiting factor in the surface layer for the phytoplankton, which decline rapidly due to active consumption by the zooplankton. In autumn, cooling in the surface layers triggers mixing of the nutrient-deficient epilimnion with the nutrient-rich hypolimnion, leading to a new development of plankton communities.

In the hypolimnion, dissolved oxygen is consumed in decay of settled detritus. The autumn mixing prompts the drop in mean oxygen values for the entire water mass. As the demand for oxygen in the hypolimnion is not very high in this simulation, we note no significant hypoxia following the mixing.

If we increase the phosphorus concentrations upstream (Simulation 2, Fig. 3), the behavior of the springtime plankton is identical to that in the previous simulation but the biomass is greater. As phosphorus is highly concentrated in inflow, nitrogen becomes a limiting factor in the epilimnion before phosphorus. This situation, linked to the rise in temperature and the decreased turbulence, fosters the development of Cyanobacteria, which assimilate excess phosphorus and fix dissolved atmospheric nitrogen. During the autumn mixing, the impact of Cyanobacteria is so great that other algae can no longer develop. The Cyanobacteria decline when the medium is more turbulent and the temperatures lower. In this case, as the Cyanobacteria are not consumed, there is only one period of zooplankton development, in the spring. 
At the end of summer, the hypolimnion is anoxic, and the autumn mixing triggers a serious drop in oxygen concentrations throughout the water mass, which may be fatal to certain fish species.

If high phosphorus concentrations are maintained over several years (Simulation 3, Fig. 4), one reaches a more pronounced situation of eutrophy, with major declines in oxygen level, even in the epilimnion.

The model results correspond closely to observations on a number of sites. For example, the first simulation could well apply to Sainte-Croix, an oligotrophic lake (Pourcher \& Salençon 1990). Variations in the plankton communities at Pareloup situate this particular reservoir somewhere between the first and second simulations, depending on the year (Salençon \& Capblancq 1987, Salençon et al. 1988, 1989, 1990a, 1990b). The third simulation could apply to a highly eutrophicated reservoir.

Figure 5 shows the effect of two other possible types of hydraulic management : the initial conditions and inflow concentrations are identical to those in Simulation 2 ; summer turbining is through either the upper or lower outlets. Here we note a major decrease in Cyanobacteria and a marked autumn peak for consumable algae and zooplankton.

The level of the turbining outlet has no major effect on variations in the epilimnic populations. Turbining through the lower outlet, on the other hand, does permit better reoxygenation of the
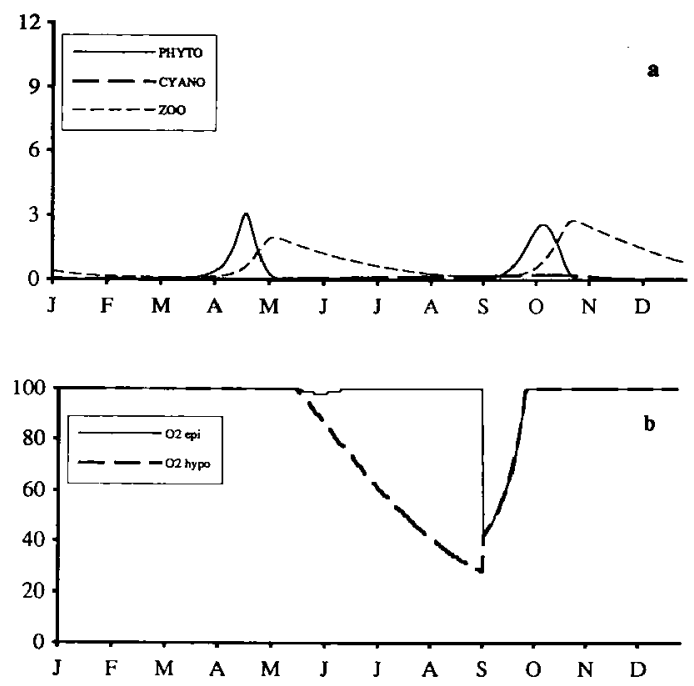

Fig. 2. Simulation 1. An oligotrophic lake with no hydroelectric power generation. Annual variation in plankton communities (consumable algae, Cyanobacteria and zooplankton) [a] and in dissolved oxygen in the epilimnion and hypolimnion [b]. Dissolved oxygen is expressed as a percentage of the concentration under conditions of saturation.

Fig. 2. Simulation 1. Cas d'un lac oligotrophe sans production hydroélectrique. Evolution annuelle des communautés planctoniques (algues consommables, cyanophycées et zooplancton) (a) et de l'oxygène dissous dans l'épilimnion et l'hypolimnion (b). L'oxygène dissous est exprimé en pourcentage de la concentration à saturation. 

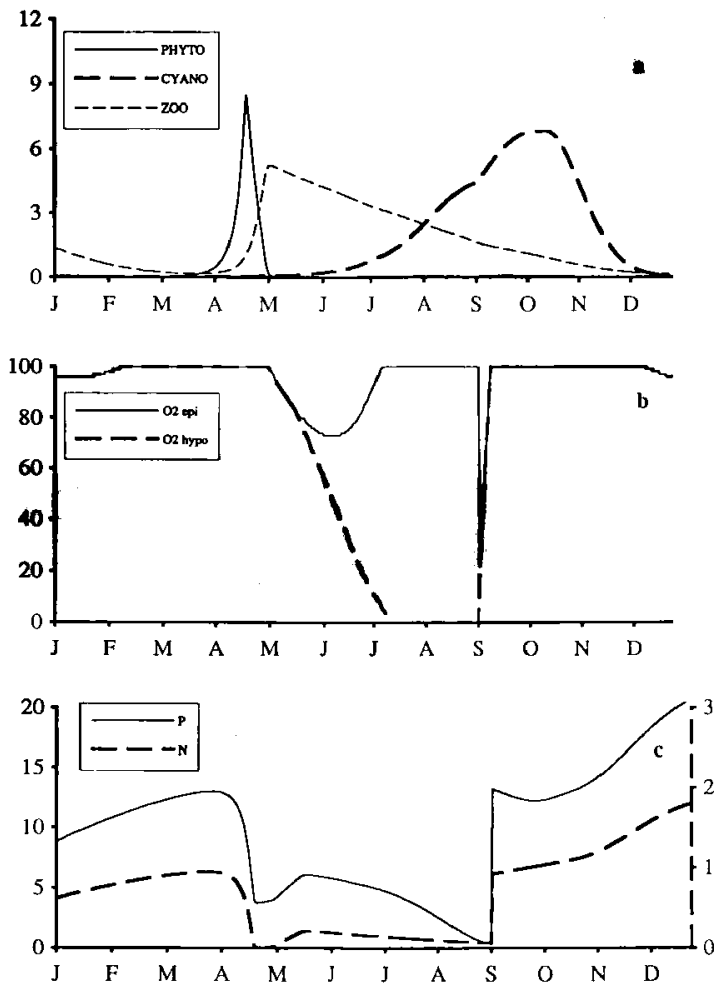

Fig. 3. Simulation 2. Annual variation in plankton communities (consumable algae, Cyanobacteria and zooplankton) [a], in dissolved oxygen in the epilimnion and hypolimnion [b], and in nutrients ( $P$ and $N)$ in the epilimnion [c]. Dissolved oxygen is expressed as a percentage of the concentration under conditions of saturation. The high nutrient concentrations and the absence of hydraulic management foster the development of Cyanobacteria.

Fig. 3. Simulation 2. Evolution annuelle des communautés planctoniques (algues consommables, cyanophycées et zooplancton) (a), de l'oxygène dissous dans l'épilimnion et l'hypolimnion (b) et des nutriments ( $P$ et $N$ ) dans l'épilimnion (c). L'oxygène dissous est exprimé en pourcentage de la concentration à saturation. Les apports importants de nutriments et l'absence de gestion hydraulique favorisent le développernent des cyanophycées. 

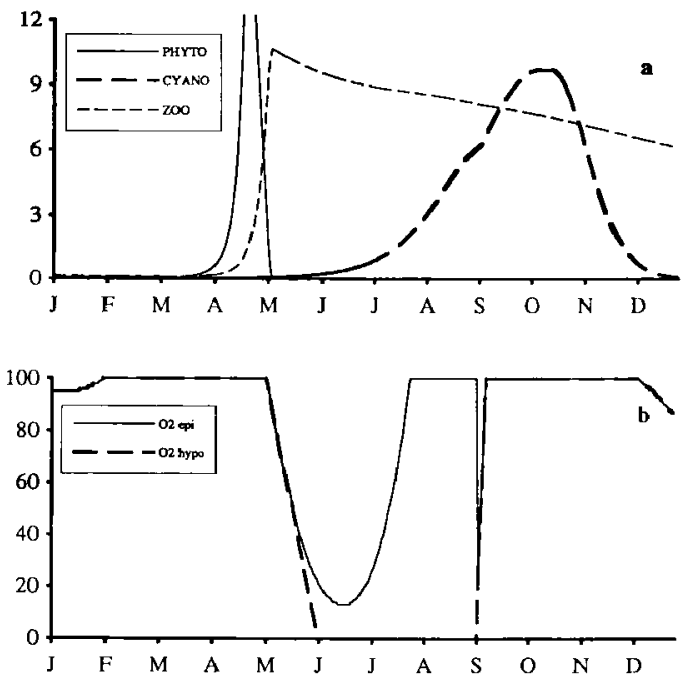

Fig. 4. Simulation 3. An eutrophic lake. Annual variation in plankton communities (consumable algae, Cyanobacteria and zooplankton) [a] and in dissolved oxygen in the epilimnion and hypolimnion [b]. Dissolved oxygen is expressed as a percentage of the concentration under conditions of saturation.

Fig. 4. Simulation 3. Cas d'un lac eutrophe. Evolution annuelle des communautés planctoniques (aigues consommables, cyanophycées et zooplancton) (a) et de l'oxygène dissous dans l'épilimnion et l'hypolimnion (b). L'oxygèné dissous est exprimé en pourcentage de la concentration à saturation.

hypolimnion than does turbining through the upper outlet, by fostering exchange between epilimnion and hypolimnion.

It would be unwise to turbine through the lower outlet at the end of summer, when the hypolimnion is anoxic ; oxidation and precipitation of iron and manganese, together with the potential effects on downstream river quality, are clearly pointed out to the novice hydraulic manager.

We must remember that the model takes into account the accumulation of nutrients in the sediment, where concentrations may become very high. When the hypolimnion is anoxic, phosphorus (and to a lesser degree, nitrogen, through de-nitrification) is released into the water mass, proportionally increasing the amount available to algae at the time of deepening of the thermocline. Therefore, when the lake is highly eutrophicated, it would be a mistake to imagine that the situation will rapidly improve if concentrations are reduced. The model represents well the inertia attribuable to the quantity of nutriment stored in the sediment. The most effective annual hydraulic management approach is to turbine at the surface in spring, to eliminate a maximum of algae and zooplankton so as to decrease the fraction in the sediment, and at the bottom in summer, to eliminate detritus which may have settled and oxygenate the hypolimnion as much as possible. It may take several years to return to acceptable conditions. 

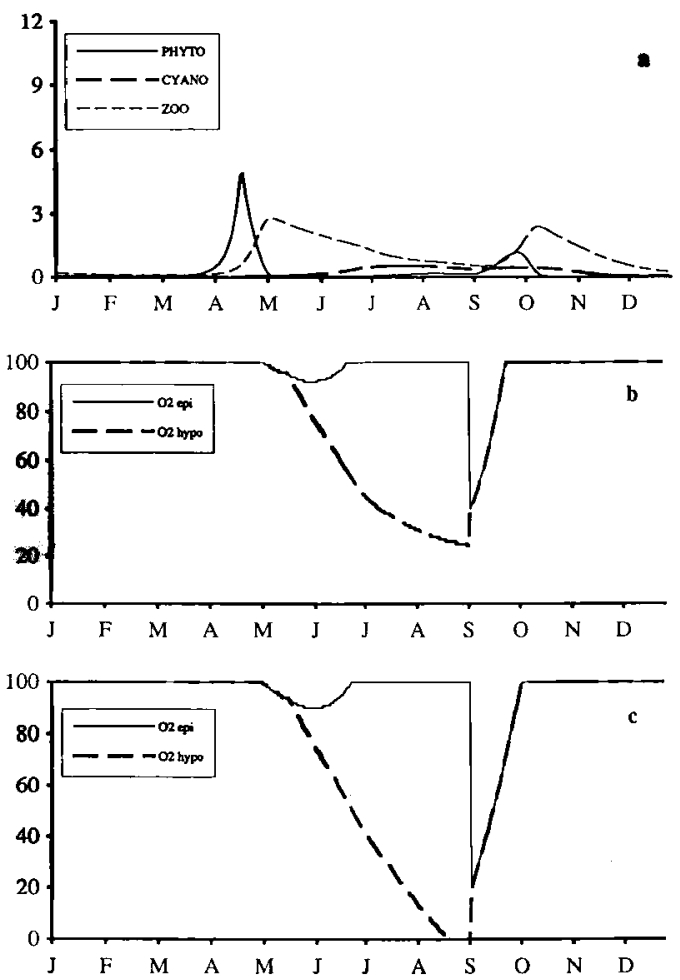

Fig. 5 Variation in plankton communities in the case of turbining during the summer [a]. Impact of the choice of outlet level on oxygenation in the water mass : turbining through the lower [b] or upper outlet [c].

Fig. 5. Evolution des communautés planctoniques dans le cas d'un turbinage pendant l'été (a). Effet đu choix de la prise d'eau sur l'oxygénation de la masse d'eau : turbinage par la prise de fond (b) ou de surface (c).

\section{Conclusion}

While " Lake Life " is an educational software program permitting the user to embark, mouse in hand, on a discovery of lake ecosystems, it is at the same time a simplified version of an actual computer code developed in the course of scientific research.
The approach followed in developing this program is identical to that followed in development of ecosystem models used in lacustrian ecology studies.

The modeled processes are relatively simplified, though the model's response is on the whole most satisfying. 
There are many potential uses for this software : as a teaching aid, in sensitizing hydraulic management specialists, in informing the general public, etc.

As the user retains control over pollutants discharged, hydraulic management and stocking with young fish, he can visualize the repercussions of his decisions on the ecosystem as a whole. In this way, he discovers the mechanisms which lead to eutrophication as well as the difficulties one encounters in trying to find remedies.

\section{To find out more}

In addition to the authors mentioned in this text, a number of works dealing with modeling aquatic ecosystems might be consulted : Bierman 1976, Canale et al. 1976, Jørgensen 1976, Jørgensen et al. 1978, Kremer \& Nixon 1978, Garçon 1981, Spain 1982, Salençon et al. 1984, Thébault 1984, Riley \& Stefan 1988, Andersen \& Nival 1989.

\section{Ack now ledgements}

"Lake Life " was developed for the EDF " Mission Environ-

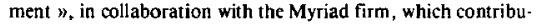
ted the graphics and the user interface. It exists now in the French version, and will soon be available in English, for use on PCcompatible computers ( $31 / 2$ " and $51 / 4$ " diskettes) and on Atari ST. It may be ordered from the Mission Environment for FF 95.

ELECTRICITE DE FRANCE, Mission Environnement, 26, rue de la Baume, 75008 Paris.

MYRIAD S.A.R.L., 4 rue de Bordeaux, 31200 Toulouse.

\section{References}

Andersen V. \& Nival P. 1989. - Modelling of phytoplankton population dynamics in an enclosed water column. $J$. mar. biol. Ass. U.K., $69: 625-646$.

Bierman V.J. Jr. 1976. - Mathematical model of the selective enhancement of blue green algae by nutrient enrichment. In : Canale R.P. (Ed.) : Modelling biochemicol processes in aquatic ecosystems, Ann Arbor Sciences, Michigan : 1-31.

Canale R.P., De Palma L.M. \& Vogel A.H. 1976. - A planktonbased food web model for Lake Michigan. In : Canale R.P. (Ed.) : Modelling biochemical processes in aquatic ecosysrems, Ann Arbor Sciences, Michigan : 33-74.

Droop M.R. 1974. - The nutrient status of algal cells in continuous culture. J. mar. biol. Ass. U.K., $54:$ 825-855.

Droop M.R. 1975. - The nutrient status of algal cells in batch culture. J. mar. biol. Ass. U.K., $55: 541-555$.

Eilers P.H.C. \& Peeters J.C.H. 1988. - A model for the relationship between light intensity and the rate of photosynthesis in phytoplankton. Ecol. Modelling, $42: 199-215$.

Garçon V. 1981. - Modélisation numérique d'un écosystème aquatique. Application au réservoir de Grangent sur la Laire. These de 3e cycle. Université Paris 7, Paris : 230 p.
Gentil S. 1982. - Analyse de système en écologie. Une étude de cas (Lac d'Aiguebelette). In Modélisation mathematique ct simulation des systemes de f'environnement. Dominante eau et végétation. Editions du CNRS, Paris : 17-62.

Jørgensen S.E. 1976. - An eutrophication model for a lake. Ecol. Modelling, $2: 147-165$.

Jargensen S.E., Mejer H. \& Friis M. 1978. - Examination of a lake model. Ecol. Modelling, 4 : 253-278.

Kremer J.N. \& Nixon S.W. 1978. - A coastal marine ecosystem. Simulation and analysis. Ecological Studies 24, SpringerVerlag. Heidelberg : $217 \mathrm{p}$.

Legras J. 1971. - Methodes et techniques de l'analyse numerique. Dunod, Paris : 323 p.

Monod J. 1942, - Recherches sur la croissance des cullures bactériennes. Hermann, Paris: $210 \mathrm{p}$.

Mullin M.M. , Stewart E.F. \& Fuglister F.J. 1975. - Ingestion by planktonic grazers as a function of concentration of food. Limnol. Oceanogr., $20: 259-262$.

Parker A. 1974, - Empirical functions relating metabolic processes in aquatic systems to environmental variables. $J$. Res. Board Can., 31 : 1550-1552.

Pourcher A.M. \& Salençon M.J. 1990. - Modélisation du plancton dans une retenue oligotrophe : Sainte-Croix sur le Verdon. Hydroécol. Appl., 1 : 91-134.

Rhee G-Yull 1978. - Effects of N : P. atomic ratios and nitrate limitation on algal growth, cell composition, and nitrate uptake. Limnol. Oceanogr., $23: 10-25$.

Riley M.J.\& Stefan H.G. 1988. - MINLAKE : a dynamic lake water quality simulation model. Ecol. Modelling, 43: 155-182.

Salençon M.J., Merle G. \& Sabaton C. 1984. - Le réseau de mesures hydrobiologiques de la retenue de Grangent (Loire) ; analyse partielle des résultats. Cahiers du laboratoire de Montereau, $15: 7.12$.

Salençon M.J. \& Capblancq J. 1987. - Etude de la retenue de Pareloup. Bilan des travaux réalisés en 1986 dans le cadre de la convention EDF.Ministère de l'Environnement. Rapport HE-31/87.5, Electricité de France, Paris : 26 p.

Salençon M.J., Thébault J.M. \& Capblancq J. 1988. - Etude de la retenue de Pareloup. Bilan des travaux réalisés en 1987 dans le cadre de la Convention EDF-Ministère de l'Environnement. Rapport HE-31/88.23, Electriçité de France, Paris : $43 \mathrm{p}$.

Salençon M.I., Thébault J.M. \& Capblancq J. 1989. - Etude de la retenue de Pareloup. Bilan des travaux réalisés en 1988 dans le cadre de la Convention EDF-Ministère de l'Environnernent. Rapport HE-31/89.13, Electricité de France, Paris : 77 p.

Salençon M.J., Thébault J.M. \& Capblancq J. 1990a. - Etude de la retenue de Pareloup. Bilan des travaux réalisés en 1989 dans le cadre de la Convention EDF-Ministère de l'Environnement. Rapport HE-31/90.17, Electricité de France, Paris : $67 \mathrm{p}$.

Salençon M.J., Thébault J.M. \& Capblancq J. 1990b. - Etude de la retenue de Pareloup. Synthèse des travaux réalisés dans le cadre de la Convention EDF-Ministère de l'Environnement (mars 1986 - mars 1990). Rapport HE-31/90.23, Electricité de France, Paris : $40 \mathrm{p}$.

Spain J.D. 1982. - Basis microcomputer models in biology, Addison-Wesley, Reading, Massachusetts : 394 p. 
Steele J.H. 1962. - Environmental control of photosynthesis in the sea. Limnol. Oceanogr., $7: 137-150$.

Steinberg C.E.W. \& Hartmann H.M. 1988. - Planktonic bloomforming Cyanobacteria and the eutrophication of lakes and rivers. Fresh. Biol, $20: 279-287$.

Talbot P., Thébault J.M., Dauta A. \& De la Nouie I., 1991. A comparative study and mathematical modeling of temperature and light on growth of three microalgae potentially useful for wastewater treatment. Water Res., $25: 465-472$.

Thébault J.M. 1984. - Modélisation des premiers niveaux du réseau trophique pélagique marin. Mise au point de modules et simulation de séries expérimentales. Thèse de $3^{e}$ cycle, Université Paris 7, Paris : 94 p.
Thébautt J.M. 1985. - Etude expérimentale de la nutrition d'un copépode comunun (Temora stylifero Dana). Effets de la temperature et de la concentration de nourriture. $J$. Exp. Mar. Biol. Ecol., 93 : 223-234.

Thébault J.M. \& Salençon M.J. - Simulation model of a mesotrophic reservoir (Lac de Pareloup. France) : Biological model. Ecol. Modelling (in press).

Zohary T.\& Breen Ch. 1989. - Environmental factors favouring the formation of Microcystis aeruginosa hyperscums in a hypertrophic lake. Hydrobiologia, $178: 179-192$. 


\section{LA VIE DU LAC}

Electricité de France
Myriad

\section{Mode d'emploi}

Allumez votre ordinateur avec une disquette système MS-DOS (version 3 ou 5) dans le lecteur A. Le logiciel ne peut fonctionner avec la version 4 de MS-DOS.

Une fois le système chargé, enlevez la disquette système et remplacez-la par la disquette $L a$ vie du lac. Tapez $\mathrm{LAC}$ suivi de retour-chariot. Une fois la version du jeu choisie et le logiciel chargé, la disquette peut être retirée du lecteur. La vie du lac peut également être copiée dans un répertoire du disque dur.

Si vous possédez une souris, celle-ci doit être installée avant de lancer $L a$ vie du lac (se reporter au manuel d'installation de votre souris).

Le logiciel nécessite une mémoire d'au moins $\$ 12$ Ko pour fonctionner. Les cartes graphiques Hercules, CGA et EGA sont automatiquement reconnues.

\section{LAKE LIFE}

Electricité de France

Myriad
Instructions for use

Start up your computer with MS-DOS system disk in disk drive A. Once the system is loaded, eject the system disk and replace it with the Lake Life disk. Type LAKE, followed by " return" : the program will load and start up. As soon as you choose the game level you want and the disk drive light goes off, eject the disk and put it away carefully.

If you have a mouse and would like to use it, you must first install it (follow the instructions in your user's manual) before running Lake Life.

Lake Life calls for at least $\$ 12$ Ko of memory. Your graphics card is automatically detected if it is a Hercules, CGA or EGA. 